\title{
Comparison between the Two Debt-Equity Swaps in China
}

\author{
Shifen Wang ${ }^{1, *}$, Zi Lin $^{1}$ \\ ${ }^{1}$ School of Economics, Shanghai University, No. 99, Shangda Road, Shanghai 200444, China \\ *Corresponding author
}

Keywords: Debt-equity Swaps, Non-performing Assets, Commercial Banks, Market-oriented.

Abstract: Since the slow growth of economy made many firms difficult to survive, the rate of bad loans in China's commercial banks increased. The control of non-performing assets became a focus of risk management in banks. Over the recent years, the industrial sector has relied on the high-leverage, high-liability method to maintain its operation. Although it worked in the short term, it would damage the long term competitiveness. In the context of structural reforms on the supply side, a new round of debt-equity swaps was launched in 2016 to speed up the de-leverage process, ease the financial burden of enterprises and reduce the rate of bad loans of banks. The new round of debt-equity swaps, different from the government-led one in the 1990s, emphasizes marketization and legalization, which brings both opportunities and challenges to commercial banks. This article introduces the background of the restart of the debt-equity swaps from the perspective of industrial sector and commercial banks. After that, it introduces the features and differences of the debt-equity swaps led by the government in the late 1990s and the market-oriented debt-equity swaps of this time. Then, by reviewing the domestic research on debt-equity swaps and the disposal of non-performing assets of commercial banks, the article points out the problems faced by market-oriented debt-equity swaps of this time. In the end, it puts forward some proposals for commercial banks to implement debt-equity swaps.

\section{Background of the Restart of Debt-equity Swaps}

Table 1. The Rate of Debt in Non-financial Industrial Sector out of GDP

\begin{tabular}{|c|c|c|c|c|c|}
\hline Years & China & Euro Zone & All Economies & Developed Economies & Developing Economies \\
\hline 2011 & 121.3 & 103.8 & 80.6 & 86.2 & 69.8 \\
\hline 2012 & 132.1 & 105.2 & 85.2 & 89.1 & 78.3 \\
\hline 2013 & 142.4 & 103.2 & 87.1 & 88.4 & 84.9 \\
\hline 2014 & 151.7 & 105.6 & 85.2 & 82.9 & 89.0 \\
\hline 2015 & 157.7 & 109.1 & 91.0 & 87.6 & 96.7 \\
\hline
\end{tabular}

Sources: Edited according to the data of BIS Statistics Explorer

Over the past years, the low rates of economic growth led to high rates of leverage in the industrial sector. The banking industry faced the problem of great decline of profits after years of 
fast growth. Both the amount and rates of bad loans of commercial banks began to climb. Debt-equity swaps became a feasible method to save the banks from difficulties.

When China's economy grew fast, the demand for capital by the firms increased. The amount of debt financing expanded as well to have developed a model of operation on borrowings. The level of debt in non-financial industrial sector of China was much higher than international average.

The declining profitability and the increasing leverage of enterprises pushed up the rate of bad loans, which had negative impacts on the rate of profit of commercial banks. Their net profit in 2011 was RMB1041.2 billion, an annual increase of 36.34\%. However, that in 2015 was RMB1592.6 billion, 2.43\% increase year on year only. At the same time, the rate of bad loans of the commercial banks, $1.00 \%$ in 2011 , grew to $1.67 \%$ in 2015 , an increase of $67 \%$. In contrast, the provision coverage rate of the banking industry decreased step by step. It was $278.1 \%$ in 2011 , but in 2015 it was $181.18 \%$ only. Judged by the above data, the rate of bad loans would continue for a fairly long period. The pressure and impetus of the commercial banks to reduce the bad loans would further increase.

Table 2. Statistical Information of Commercial Banks in China

\begin{tabular}{|c|c|c|c|c|}
\hline Quarters & Net Profits & Profit-asset Ratio & Provision Coverage Rates & Rates of Bad Loans \\
\hline 2011 & 10412 & $1.30 \%$ & $278.10 \%$ & $1.00 \%$ \\
\hline 2012 & 12386 & $1.28 \%$ & $295.51 \%$ & $0.95 \%$ \\
\hline 2013 & 14180 & $1.27 \%$ & $282.70 \%$ & $1.00 \%$ \\
\hline 2014 & 15548 & $1.23 \%$ & $232.06 \%$ & $1.25 \%$ \\
\hline 2015 & 15926 & $1.10 \%$ & $181.18 \%$ & $1.67 \%$ \\
\hline
\end{tabular}

Sources: Statistics by China Banking Regulatory Commission 2011-2015

Thus, Chinese government carried out a series of policies to make more efforts to implement debt-equity swaps, so as to decrease the rates of leverage and bad loans.

On October 10, 2016, the State Council of China published Several Comments on Actively and Steadily Decreasing the Rate of Leverage of Enterprises and its attachment Directory Comments on Debt-equity Swaps by the Commercial Banks, offering the specific principles, methods and requirements for the market-oriented debt-equity swaps. It marked the start of a new round of debt-equity swaps. Early in 2018, the State Development and Reform Committee, together with the People's Bank of China, the Ministry of Finance and the Banking and Insurance Regulatory Commission, published The Notes on Several Specific Policy Problems in the Implementation of Market-oriented Debt-equity Swaps, making it clear that it allows the equity and debt combining comprehensive method to lower the rate of leverage of enterprises. Since the Commercial Bank Law does not allow banks to hold stocks of any non-banking companies, on June 29 the Banking and Insurance Regulatory Commission published The Managing Method of the Financial Assets Investment Companies, encouraging commercial banks to set up financial investment companies to work on debt-equity swaps and the supporting business.

Table 3. The Wholly Owned Subsidiaries Set Up by the Five Banks

\begin{tabular}{|c|c|c|c|}
\hline & Wholly Owned Subsidiaries & Registered Capital & Time \\
\hline ABC & ABC Assets Management Company & RMB10 billion & Nov. 23, 2016 \\
\hline ICBC & ICBC Assets Management Company & RMB12 billion & Dec. 9, 2016 \\
\hline CBC & CBC Trust Assets Management Company & RMB12 billion & Dec. 21, 2016 \\
\hline BOC & BOC Assets Management Company & RMB10 billion & Nov. 22, 2016 \\
\hline BCM & BCM Assets Management Company & RMB10 billion & Jan. 19, 2017 \\
\hline
\end{tabular}

Sources: www.stcn.com 
According to the data released by the Banking and Insurance Regulatory Commission, by the end of February 2019, the amount of the signed contracts for the debt-equity swaps topped RMB2 trillion. The traded amount was 620 billion, $31 \%$ of the contracted amount. ${ }^{1}$

\section{Literature Review}

There were some studies on debt-equity swaps by scholars. ZHOU Xiaochuan (1999) thought that debt-equity swaps was a means of asset preservation by commercial banks when the loan-taking corporations met difficulties in business. The difficult firms would recover profitability so as to reduce the loss of credit of the banks. ${ }^{2}$ YANG Kaisheng (2016) argued that the principles to select the debt-equity swaps should include the market prospects of products and the ability of corporate governance of the firms rather than to save those that should be eliminated. It was important to allow the new stock holders to play due roles. ${ }^{3}$ MA Xili (2018) regarded that with the progress of technology and the financial market of China, the traditional way of debt-equity swaps couldn't meet the demand of the commercial banks to handle the bad loans. Some more market-oriented, comprehensive and diversified methods, such as internet + and asset securitization, were emerging. ${ }^{4}$

\section{Review of the First Debt-equity Swap in Last Century}

In 1999 China had carried out the first debt-equity swaps successfully, aiming to reduce the bad loans of the Big Four (state-owned commercial banks).

At that time, the rate of growth of China's economy declined from more than $10 \%$ to $7 \%$ as the results of a series of bad events such as the Asian Crisis in $1997 .{ }^{5}$ The number of the enterprises in the red and the amount of deficit were big. In the first half of 1999, more than half of the big to mid-sized state-owned enterprises suffered losses. About 95\% of the financial expense was interest payment. The rate of bad loans of the Big Four went up fast from 32.34\% in 1998 to $41 \%$ in $1999 .^{6}$

In 1999, financed by appropriation of the government and the issuance of the bonds to the Big Four, four asset management companies (AMCs) were set up (Huarong, Changcheng, Dongfang and Xinda) to take off the bad loans of the Big Four. The State Economic Committee gave the AMCs a name list of the firms that were recommended for swaps. The latter would assess the firms in the list independently before they confirmed the firms that would go through swaps. The selected companies should meet the "Five Criteria" and "Five Categories" requirements set by the government. The bad loans of commercial banks were sold to the four AMCs at their face value. The AMCs would choose some firms to do the debt-equity swaps.

In December 1999, the State Economic Committee recommended 601 debt-equity swaps firms with bad loans of RMB 459.6 billion. In August 2000, the AMCs signed the framework agreements of swaps with 580 firms, swapping RMB405.1 billion, 29\% of the total amount of RMB1393.9 billion of bad loans that the 4 AMCs accepted from the Big Four banks. ${ }^{7}$ This indeed eased the

\footnotetext{
${ }^{1}$ Website of the Banking and Insurance Regulatory Commission.

${ }^{2}$ ZHOU Xiaochuan. Several Problems about the Debt-equity Swaps[J]. Comparison of Economic and Social Systems, 1999(06):1-9.

${ }^{3}$ YANG Kaisheng. Meditations on the Debt-equity Swaps[J]. Tsinghua Financial Review, 2016(05):48-49.

${ }^{4}$ MA Lixi. A Study on the Coping Strategy over the Bad Loans of Commercial Banks in the Background of the Strict Regulations[J]. Modern Management Science, 2018(01):33-35.

${ }^{5}$ State Bureau of Statistics.

${ }^{6}$ Wind Database.

${ }^{7}$ LOU Feipeng. The Historical Experience and the Suggestions of Implement for the Debt-equity Swaps of the Bad Loans of Commercial Banks[J]. Southwest Finance, 2016(06):52-56.
} 
operating difficulties of the state-owned companies and lowered the rates of bad loans of the commercial banks.

Table 4. Results of Debt-equity Swaps by the 4 AMCs (March 2003) (RMB billion)

\begin{tabular}{|c|c|c|c|}
\hline AMCs & Handled Assets & Recovered Debts & Rate of Recovery \\
\hline Huarong & 96.4 & 21 & $21.82 \%$ \\
\hline Changcheng & 110 & 11.1 & $10.06 \%$ \\
\hline Dongfang & 48.3 & 12.3 & $25.36 \%$ \\
\hline Xinda & 88.7 & 27.2 & $30.62 \%$ \\
\hline
\end{tabular}

Sources: Sohu Finance

Table 5. Comparison of the Characters of the Two Debt-equity Swaps

\begin{tabular}{|c|c|c|}
\hline & Debt-equity Swaps in Last Century & Debt-equity Swaps since 2016 \\
\hline Mode & Government-led & Market and Legal Oriented \\
\hline $\begin{array}{l}\text { Selection of } \\
\text { the target } \\
\text { companies }\end{array}$ & $\begin{array}{l}\text { Recommended by the government and approved } \\
\text { by the AMCs. The selected companies were } \\
\text { considered to have the market for their products, } \\
\text { high management level and advanced } \\
\text { technologies. Their difficulties came from high } \\
\text { debt only. The reason could be information } \\
\text { asymmetry due to the absence of market } \\
\text { selection. }\end{array}$ & $\begin{array}{l}\text { Chosen by all the related stakeholders } \\
\text { through negotiations. The targeted companies } \\
\text { had good potential of development or were } \\
\text { key companies in industry. The big debts } \\
\text { were temporary, caused by business cycles, } \\
\text { high liability rates or starting stage burdens. }\end{array}$ \\
\hline Processes & $\begin{array}{l}\text { In nature, the swap of this round was to turn the } \\
\text { banks' credit of the companies into the shares of } \\
\text { the AMCs, which didn't have material } \\
\text { participation of the management. The ownership } \\
\text { of the firms was not diversified so that there were } \\
\text { not fundamental improvements in management, } \\
\text { operation and competitiveness of the firms. }\end{array}$ & $\begin{array}{l}\text { Banks changed the loans into the shares of the } \\
\text { companies through brokers. The brokers were } \\
\text { encouraged to cooperate with investment } \\
\text { funds and to compete other brokers for the } \\
\text { swaps in open market. } \\
\text { In the ownership change, the whole rights of } \\
\text { the new stockholders were protected by the } \\
\text { laws and rules. }\end{array}$ \\
\hline $\begin{array}{l}\text { Entry and } \\
\quad \text { exit }\end{array}$ & $\begin{array}{l}\text { The method of exit was not arranged so that the } \\
\text { interest of banks and AMCs was not protected. } \\
\text { The shares were not priced in the market, causing } \\
\text { the pressures on the banks and AMCs to recover } \\
\text { the costs. Up to now, some AMCs still held some } \\
\text { shares that were difficult to liquidate because the } \\
\text { immature stock exchange market led to the } \\
\text { absence of effective way of bailout. }\end{array}$ & $\begin{array}{l}\text { The methods were more various and } \\
\text { market-oriented. If the companies with } \\
\text { debt-equity swaps were listed in the stock } \\
\text { exchange, the brokers could exit by selling } \\
\text { the shares in the exchange. If they were not } \\
\text { listed, the brokers were encouraged to exit } \\
\text { through } M \text { \& A, trade in the small and } \\
\text { medium stock transfer system, and IPO. }\end{array}$ \\
\hline Fund raising & $\begin{array}{l}\text { Appropriation by the government or issuing } \\
\text { special bonds to the Big Four banks. }\end{array}$ & $\begin{array}{l}\text { Funds were raised by the brokers through } \\
\text { market-oriented methods, such as to issue } \\
\text { bonds to investors, issue special financial } \\
\text { bonds to corporate investors. The government } \\
\text { would simplify approval process or offer tax } \\
\text { concession. }\end{array}$ \\
\hline
\end{tabular}

\section{Conclusions}

For those difficult firms with heavy burden of debts, the debt-equity swaps could help them lower the rate of leverage, reduce the costs of operation and lift them out of troubles. On the other hand, the swaps could reduce the potential volume of bad loans of the banks and guard against financial risks. This article compares the features of the 2 debt-equity swaps. The first one was mainly 
directed by the government's orders. The second one was mainly determined by the market force, and the risks were guarded by the laws. In this one, the role of the government was to make the rules, improve the policies, and keep the market order and social stability.

\section{References}

[1] GUO Shuhua, LI Xiaoxi, XU Youdan. The Characteristics and the Difficulties of the Market-Oriented Debt-equity Swaps, and the Solutions[J]. South China Finance, 2017(11):59-65.

[2] JIA Meiyv, ZHANG Junyan. The Analyses on the Impact of the New Round Debt-equity Swaps on China's Commercial Banks and the Coping Strategies[J]. Current Finance, 2017(24):74-75.

[3] LOU Feipeng. The Historical Experience and the Suggestions of Implement for the Debt-equity Swaps of the Bad Loans of Commercial Banks[J]. Southwest Finance, 2016(06):52-56.

[4] MA Lixi. A Study on the Coping Strategy over the Bad Loans of Commercial Banks in the Background of the Strict Regulations[J]. Modern Management Science, 2018(01):33-35.

[5] YANG Kaisheng. Meditations on the Debt-equity Swaps[J]. Tsinghua Financial Review, 2016(05):48-49.

[6] ZHOU Xiaochuan. Several Problems about the Debt-equity Swaps[J]. Comparison of Economic and Social Systems, 1999(06):1-9. 